Journal of

Synchrotron

Radiation

ISSN 0909-0495

Editors: G. Ice, Å. Kvick and T. Ohta

\title{
XANES speciation of mercury in three mining districts - Almadén, Asturias (Spain), Idria (Slovenia)
}

\author{
José Maria Esbrí, Anna Bernaus, Marta Ávila, David Kocman, Eva M. \\ García-Noguero, Beatriz Guerrero, Xavier Gaona, Rodrigo Álvarez, \\ Gustavo Perez-Gonzalez, Manuel Valiente, Pablo Higueras, Milena Horvat \\ and Jorge Loredo
}

J. Synchrotron Rad. (2010). 17, 179-186

Copyright (C) International Union of Crystallography

Author(s) of this paper may load this reprint on their own web site or institutional repository provided that this cover page is retained. Republication of this article or its storage in electronic databases other than as specified above is not permitted without prior permission in writing from the IUCr.

For further information see http://journals.iucr.org/services/authorrights.html

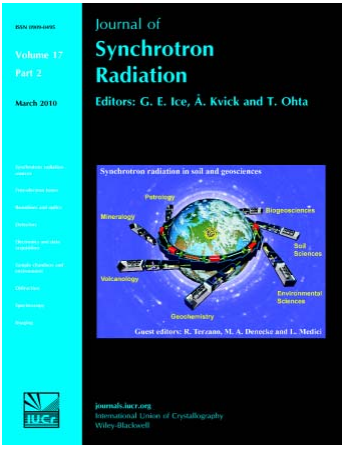

Synchrotron radiation research is rapidly expanding with many new sources of radiation being created globally. Synchrotron radiation plays a leading role in pure science and in emerging technologies. The Journal of Synchrotron Radiation provides comprehensive coverage of the entire field of synchrotron radiation research including instrumentation, theory, computing and scientific applications in areas such as biology, nanoscience and materials science. Rapid publication ensures an up-to-date information resource for scientists and engineers in the field.

Crystallography Journals Online is available from journals.iucr.org 
Journal of

Synchrotron

Radiation

ISSN 0909-0495

Received 22 June 2009

Accepted 15 January 2010
(C) 2010 International Union of Crystallography

Printed in Singapore - all rights reserved

\section{XANES speciation of mercury in three mining districts - Almadén, Asturias (Spain), Idria (Slovenia)}

\author{
José Maria Esbrí, ${ }^{\mathrm{a} *}$ Anna Bernaus, ${ }^{\mathrm{b}}$ Marta Ávila, ${ }^{\mathrm{b}}$ David Kocman, \\ Eva M. García-Noguero, ${ }^{a}$ Beatriz Guerrero, ${ }^{b}$ Xavier Gaona, ${ }^{b}$ Rodrigo Álvarez, \\ Gustavo Perez-Gonzalez, ${ }^{b}$ Manuel Valiente, ${ }^{b}$ Pablo Higueras, ${ }^{a}$ Milena Horvat ${ }^{c}$ and \\ Jorge Loredo ${ }^{\mathrm{d}}$
}

\begin{abstract}
${ }^{a}$ Departamento de Ingeniería Geológica y Minera, Escuela Universitaria Politécnica de Almadén, Universidad de Castilla-La Mancha, 13400 Almadén (Ciudad Real), Spain, ${ }^{\mathbf{b}}$ Grup de Tècniques de Separació en Química (GTS), Departament de Química, Universitat Autónoma de Barcelona, 08193 Bellaterra (Barcelona), Spain, ${ }^{\mathbf{c}}$ Department of Environmental Sciences, Jozef Stefan Institute, Ljubljana SI-1001, Slovenia, and ${ }^{\mathbf{d}}$ Departamento de Explotación y Prospección de Minas, Universidad de Oviedo, Oviedo 33004, Spain. E-mail: josemaria.esbri@uclm.es
\end{abstract}

\begin{abstract}
The mobility, bioavailability and toxicity of mercury in the environment strongly depend on the chemical species in which it is present in soil, sediments, water or air. In mining districts, differences in mobility and bioavailability of mercury mainly arise from the different type of mineralization and ore processing. In this work, synchrotron-based X-ray absorption near-edge spectroscopy (XANES) has been taken advantage of to study the speciation of mercury in geological samples from three of the largest European mercury mining districts: Almadén (Spain), Idria (Slovenia) and Asturias (Spain). XANES has been complemented with a single extraction protocol for the determination of $\mathrm{Hg}$ mobility. Ore, calcines, dump material, soil, sediment and suspended particles from the three sites have been considered in the study. In the three sites, rather insoluble sulfide compounds (cinnabar and metacinnabar) were found to predominate. Minor amounts of more soluble mercury compounds (chlorides and sulfates) were also identified in some samples. Single extraction procedures have put forward a strong dependence of the mobility with the concentration of chlorides and sulfates. Differences in efficiency of roasting furnaces from the three sites have been found.
\end{abstract}

Keywords: mercury speciation; XANES; Almadén; Idria; Asturias; bioavailability.

\section{Introduction}

Assessing the distribution and mobilization of heavy metals in the environment as a result of natural processes or anthropogenic activities is of special relevance in mining districts. Mercury $(\mathrm{Hg})$ is one of the most toxic heavy metals, as some of its compounds can be absorbed by living tissues in large doses and these compounds or their derivatives can concentrate and be stored over long periods of time. Through the food chain, mercury can eventually affect human beings and cause chronic or acute damage (Förstner, 1998). From a toxicological point of view, the toxicity of heavy metals is primarily controlled by the dose and the corresponding chemical speciation. Accordingly, many recent studies have been devoted to assess heavy metal speciation either through direct or indirect approaches (Horvat, 2005). The most widely used methods are based on sequential selective extractions (Bloom et al., 2003;
Kocman et al., 2004) and X-ray absorption spectroscopy (XAS) techniques (Kim et al., 2000, 2003, 2004; Slowey et al., 2005a,b; Bernaus et al., 2005a,b, 2006a,b). Alternative techniques are based on $\mathrm{Hg}$ pyrolysis followed by AAS detection, which allows the differentiation among cinnabar, metallic $\mathrm{Hg}$ and matrix-bound $\mathrm{Hg}$ (Biester et al., 1999, 2000). XAS techniques have been shown to provide reliable information on the speciation of mercury without requiring sample pretreatment (Kim et al., 2004; Slowey et al., 2005a,b; Bernaus et $a l ., 2006 a$ ). The application of XAS to mercury speciation provides results with good consistency in terms of $\mathrm{Hg}-\mathrm{S} / \mathrm{Hg}-$ non-S and $\mathrm{Hg}$-insoluble/ $\mathrm{Hg}$-soluble ratios according to wetchemistry data (Kim et al., 2003). On the other hand, one of the main limitations of the XAS methods refers to their high detection limits.

Among XAS techniques, both EXAFS (extended X-ray absorption fine structure) and XANES (X-ray absorption 
near-edge) spectroscopies have been previously used for the speciation of mercury in different matrices, such as mine ores and wastes (Kim et al., 2000, 2004), fish (Harris et al., 2003), contaminated soils (Bernaus et al., 2006a) and hyacinths (Riddle et al., 2002), and in studies of interactions between mercury and soil minerals (Bernaus et al., 2005b). According to data available in the literature (Webb, 2005), XANES is particularly useful for analysis of geochemical and environmental systems and has been preferred in this study. This is in agreement with our previous experience and the known XANES fingerprint differences among the $\mathrm{Hg}$ compounds mainly expected in mining environments (Bernaus et al., $2005 a, 2006 a, b)$.

In this framework, mobility studies represent a good complement to purely speciation techniques, as they represent a more empirical approach to the understanding of mercury transfer among inorganic, organic and biological reservoirs.

In line with the publications by Brown and co-workers on the characterization of mercury mines in north America (Kim et al., 2000, 2004), this work aims at providing a further understanding and a general perspective on the role of mercury in three of the most important mercury mining districts in Europe, namely Almadén and Asturias in Spain and Idria in Slovenia.

\section{Materials and methods}

\subsection{Study sites}

Among the three mining districts selected in this study, Almadén and Idria have been the largest world mercury producers in historic times, both having a monometallic character. On the other hand, Asturias has a more complex mineralization, with high proportions of arsenic in its paragenesis. It is important to highlight that Almadén is the largest cinnabar $(\mathrm{HgS})$ deposit in the world and it has been active since the Roman times until the present days, having accounted for about one third of the total $\mathrm{Hg}$ world production (Hernández et al., 1999; Saupé, 1990). Metallurgical processing in the study area evolved from Bustamante furnaces, with roasting temperatures over $873 \mathrm{~K}$, to Pacific furnaces in the last century, reaching temperatures of up to $1073 \mathrm{~K}$.

From a mineralogical point of view, soils at Almadén area are mainly represented by quartz and a diversity of clay-type minerals such as chlorite, illite, kaolinite and pyrophyllite and high contents of carbonates which correspond to a region with shales and quartzites as main components of the stratigraphic sequence (García Sansegundo et al., 1987, among others). The high content of carbonates can be explained by the presence of mafic magmatic rocks strongly affected by propilitic, carbonate-rich alteration processes in the stratigraphic sequence (Hall et al., 1997; Higueras et al., 2000).

Idria mining district is, like Almadén, a monometallic ore deposit, with higher proportions of native mercury and hosted in carbonate host rocks. The mineralization appears as two main species: cinnabar and native mercury. Other minerals
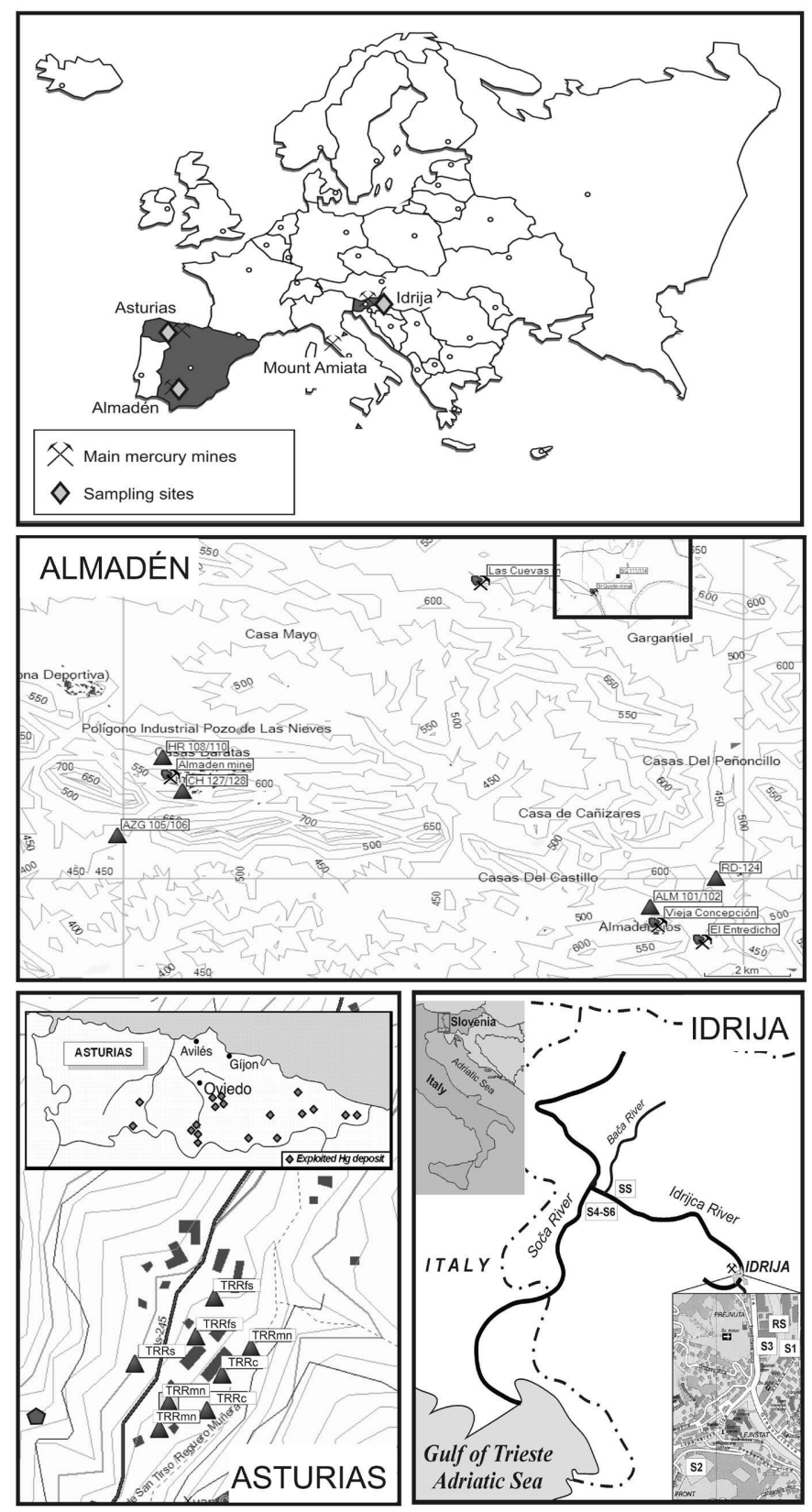

Figure 1

Sampling locations, mines and metallurgical sites of the three mercury mining districts, Almadén, Asturias and Idria. Abbreviations: ALM: Almadenejos decommissioned metallurgical plant; RD: Valdeazogues river downstream; El Entredicho: decommissioned open pit; AZG: Azogado stream; CH: dump of Almadén mine; HR: Huerta del Rey; SQ: San Quintín (real location: $50 \mathrm{~km}$ to the east of Almadén); TRR: El Terronal mine. (See Table 1 for more details.)

appearing in the paragenesis are metacinnabar, pyrite, marcasite, dolomite, calcite, kaolinite, epsomite and melanterite.

The mineralogical characterization of Idria samples reveals carbonate bedrocks as main components of the stratigraphic sequence, with the exception of the meadow soil from the Pront Hill which was developed on carboniferous clastic rocks. River bed and suspended sediments are composed of silica, clay minerals, Fe and $\mathrm{Al}$ oxides, hydroxides and carbonates as 
Table 1

Samples collected at the three mining districts.

\begin{tabular}{|c|c|c|c|}
\hline Location & ID & Sampling area & Material \\
\hline \multicolumn{4}{|l|}{ Almaden site } \\
\hline \multirow[t]{3}{*}{ Almadén } & HR & Huerta del Rey metallurgical precinct & Soils from old metallurgical plant of the 17 th century \\
\hline & $\mathrm{CH}$ & Main dump of Almadén mine & Dump material, sediments and riparian soils \\
\hline & AZG & Azogado stream & Riparian soils and stream sediments \\
\hline Almadenejos & ALM & Decommissioned metallurgical plant & Soils from the metallurgical precinct \\
\hline Valdeazogues river & $\mathrm{RD}$ & Downstream of El Entredicho pit & Suspended particles \\
\hline San Quintín & SQ & Decommissioned $\mathrm{Pb}-\mathrm{Zn}-\mathrm{Ag}$ mine & $\begin{array}{l}\text { Mine wastes and soils from an old flotation plant tested for } \\
\text { cinnabar treatment }\end{array}$ \\
\hline \multicolumn{4}{|l|}{ Idria site } \\
\hline \multirow[t]{4}{*}{ Soils } & $\mathrm{S} 1-\mathrm{S} 3$ & Vicinity of the metallurgical plant & Soils \\
\hline & $\mathrm{S} 2$ & Pront Hill & Meadow soils \\
\hline & S4 & Idrijca merges with the river Baca & $\begin{array}{l}\text { Alluvial soil samples collected along the river Idrijca } 40 \mathrm{~km} \\
\text { downstream from the mine }\end{array}$ \\
\hline & S5-S6 & Alluvial plain confluence of Idrijca and Baca rivers & Soils from a deep profile at depth $50 \mathrm{~cm}(\mathrm{~S} 5)$ and $100 \mathrm{~cm}$ (S6) \\
\hline \multirow[t]{2}{*}{ Sediments } & RS & $\begin{array}{l}\text { Idrijca river, } 35 \mathrm{~km} \text { downstream from the mine before } \\
\text { Baca river inflow }\end{array}$ & $\begin{array}{l}\text { River bed sediments of a composite sample taken within a } \\
\text { distance of } 50 \mathrm{~m} \text { with grain size }<0.063 \mathrm{~mm}(\mathrm{RS} 1) \text { and } \\
0.063-2 \mathrm{~mm}(\mathrm{RS} 2)\end{array}$ \\
\hline & SS & $\begin{array}{l}\text { Idrijca river, } 35 \mathrm{~km} \text { downstream from the mine before } \\
\text { Baca river inflow }\end{array}$ & $\begin{array}{l}\text { Suspended river sediments of a composite sample taken } \\
\text { within a distance of } 50 \mathrm{~m} \text { with grain size }<0.063 \mathrm{~mm} \text { (SS1) } \\
\text { and } 0.063-2 \mathrm{~mm}(\mathrm{SS} 2)\end{array}$ \\
\hline \multicolumn{4}{|l|}{ Asturias site } \\
\hline Mine tailings & TRRmn & Mine and metallurgical plant & Dumps in the vicinity of rotary furnaces \\
\hline Calcines & TRRc & Mine and metallurgical plant & Calcination waste \\
\hline Soil & TRRs & Metallurgical plant & Soil from an abandoned chimney channel \\
\hline Forest soils & TRRfs & El Terronal mine & Forest soils from the mining area \\
\hline
\end{tabular}

remnants of carbonate and clastic rock weathering products in the Idrijca catchment (Kanduč et al., 2008).

Asturias district shows a more complex mineralogy, with mercury present as cinnabar, but with variable metacinnabar and metallic mercury proportions and with other metallic minerals such as orpiment, realgar, melnikovite, chalcopyrite, arsenopyrite, stibnite and galena (Loredo et al., 1999). This site has an intense metallurgical activity with lower calcinations temperatures in their rotary furnaces (over $853 \mathrm{~K}$ ) than the other mining districts (Luque \& Gutiérrez, 2006).

The total mercury concentration in soils and sediments of these three mining districts is well documented (Berzas Nevado et al., 2003; Higueras et al., 2003, 2006; Gray et al., 2004; Horvat et al., 2002), although only a few studies dealt with inorganic mercury speciation (Bernaus et al., 2005a, 2006a; Kocman et al., 2004; Biester et al., 1999, 2000).

\subsection{Sample collection, storage and preparation}

Samples from the main mines, metallurgical plants and drainage network of the three districts were considered in this study (Fig. 1). A list of samples, corresponding acronyms used in the text and short descriptions is provided in Table 1.

The samples of soils, mine tailings, calcines and riparian soils from Almadén were taken at a depth of 0-20 cm, stored in polyethylene bags and sieved at the Almadén School of Mines to below a grain size of $2 \mathrm{~mm}$. Samples of suspended particles were collected from the water column, sedimented in laboratory and air-dried in a clean room. The rest of the samples were air-dried to prevent mercury losses, homogenized and ground before analysis.
Soil samples from Idria were taken with a stainless steel auger at a depth of $0-10 \mathrm{~cm}$ and stored in polyethylene containers. Suspended river sediment was sampled during a flood event of the Idrijca river by means of a net drift sampler (Kocman, 2008). After removal of gravel, stones and plant residues, river bed and suspended sediments were sieved and separated in two grain-size fractions: $<0.063 \mathrm{~mm}$ and $0.063-$ $2 \mathrm{~mm}$. Before analyses, samples were dried at $303 \mathrm{~K}$ for three days (to a constant weight) in the dark, then ground and homogenized in an agate mortar and transferred into polypropylene containers.

The samples from Asturias area were collected in the La Peña-El Terronal mine site, near the town of Mieres. The site includes dumps, calcines, contaminated soils and a chimney channel used to transport roasting smoke to the top of a mount. Soils, riparian soils and mine tailings samples $(\sim 1.5 \mathrm{~kg})$ were collected at $10-30 \mathrm{~cm}$ depth, stored in polyethylene bags, air-dried in a clean room and sieved in the laboratory using a $0.1 \mathrm{~mm}$ sieve.

All solid samples from the three mining districts were prepared for synchrotron analysis using an aliquot, mixed with polyethylene (IR quality), homogenized with a vortex for $2 \mathrm{~min}$ and pressed to a pellet with 5 ton $\mathrm{cm}^{-2}$ of pressure.

\subsection{Chemical characterization}

Total mercury content of all solid samples was determined by Zeeman atomic absorption spectrometry using highfrequency modulation of light polarization (ZAAS-HFM) with a Lumex RA-915+ analyzer (Sholupov \& Ganeyev, 1995). The detection limit of this technique for soils and sediments 
samples is $0.5 \mu \mathrm{g} \mathrm{Hg} \mathrm{kg}^{-1}$. For accuracy, certified reference material (CRM-025) was analyzed simultaneously.

\subsection{XANES measurements}

XANES measurements were performed at the synchrotron facility Hamburger Synchrotronstrahlungslabor (HASYLAB) in Hamburg (Germany) at the bending-magnet beamline A1 (see further details by Bernaus et al., 2005b). All measurements were carried out at room temperature. The beamline set-up consisted of a $\mathrm{Si}(111)$ double-crystal monochromator, three ionization chambers as transmission detectors and a seven-pixel Ge fluorescence detector.

The photon absorption of mercury was recorded at its $L_{\text {III }}$ energy $(12284 \mathrm{eV})$. Fluorescence detection mode was used for the analysis of all samples, except for the reference compounds whose spectra were recorded in transmission mode. References for XANES fingerprint adjustments included minerals and pure compounds: $\mathrm{HgCl}_{2}, \mathrm{HgSO}_{4}, \mathrm{HgO}$, $\mathrm{CH}_{3} \mathrm{HgCl}, \mathrm{Hg}_{2} \mathrm{Cl}_{2}$ (calomel), $\mathrm{HgS}_{\text {red }}$ (cinnabar), $\mathrm{HgS}_{\text {black }}$ (metacinnabar), $\mathrm{Hg}_{2} \mathrm{NCl}_{0.5}\left(\mathrm{SO}_{4}\right)_{0.3}\left(\mathrm{MoO}_{4}\right)_{0.1}\left(\mathrm{CO}_{3}\right)_{0.1} \cdot \mathrm{H}_{2} \mathrm{O}$ (mosesite), $\mathrm{Hg}_{3} \mathrm{~S}_{2} \mathrm{Cl}_{2}$ (corderoite), $\mathrm{Hg}_{3}\left(\mathrm{SO}_{4}\right) \mathrm{O}_{2}$ (schuetteite) and $\mathrm{Hg}_{2} \mathrm{ClO}$ (terlinguaite). This selection was undertaken on the basis of our prior knowledge of the geochemistry of the different study areas (Horvat et al., 2002; Higueras et al., 2003, 2006; Gray et al., 2004; Kocman et al., 2004; Kanduč et al., 2008), as well as the possible weathering and anthropogenic processes taking place in each site.

XANES spectra were processed using SixPACK data analysis software package (SIXPack, 2004; see also Catalano et al., 2005; Slowey et al., 2005b; Arai et al., 2006). Spectra processing included energy correction, signal normalization and background correction. After data correction and normalization, a principal component analysis (PCA) was applied to the set of unknown spectra to determine the number of principal components required to describe the variation in the data. Then, the PCA results were used with a target transformation, which projected the spectrum from a reference compound onto the vector space defined by the components. If the target vector lay within this component space (above the 95\% confidence level), then this reference compound was selected to be present in the dataset. Finally, a linear least-squares approach was used to determine the fractional amount of each reference compound in the samples (Malinowski, 1991; Ressler et al., 2000; Wasserman et al., 1999). The quality of the target transform was given by the reduced $\chi^{2}$ value, which represents the goodness of the fit to the spectra data, and is defined as

$$
\text { reduced } \chi^{2}=\frac{1}{N-P} \sum_{i=1}^{N}\left(\chi_{i}^{\mathrm{obs}}-\chi_{i}^{\mathrm{fit}}\right)^{2}
$$

where $\chi_{i}^{\text {obs }}$ is the ordinate of the XANES spectrum measured from the sample at the $i$ th energy point, $\chi_{i}^{\text {fit }}$ is the ordinate of the fitted XANES spectrum, $N$ is the number of data points in the fitted XANES energy range (scaled by the wavenumber $k$ ) and $P$ is the number of fitted components.
A higher reduced $-\chi^{2}$ denotes that the $\mathrm{Hg}$ compounds compared possess a lower degree of similarity. This $\chi^{2}$ represents the goodness of the model fit to the spectra data using the linear combination procedure (Rehr et al., 1992).

\subsection{Mobility study (single extraction procedures)}

Assays on the mobility of mercury were performed according to the methodology reported by Perez et al. (2008). Briefly, the methodology consisted of sample extraction with $0.5 \mathrm{M} \mathrm{HCl}$ for $1 \mathrm{~h}$ with magnetic stirring. The ratio solid: water was $1 \mathrm{~g}: 20 \mathrm{ml}$. After centrifugation at 3500 r.p.m. for $10 \mathrm{~min}$, the extracts were filtered and analyzed by ICP-OES (ThermoElemental ICP-OES, model Intrepid II XLS, Franklyn, MA, USA).

\section{Results and discussion}

Total mercury content (Table 2) in the Almadén district shows high $\mathrm{Hg}$ concentrations in soil samples from metallurgical sites, which can be mainly attributed to the inefficient metallurgical techniques used in the old plants of Almadenejos and Huerta del Rey (Sumozas, 2005), with estimated roasting temperatures below $873 \mathrm{~K}$. High total mercury concentrations have also been found in sediments and riparian soils from Valdeazogues river, but especially from Azogado stream (AZG) $\left(2816 \mu \mathrm{g} \mathrm{Hg} \mathrm{g}^{-1}\right)$. The latter is in good agreement with previous studies undertaken at the same sampling site (Gray et al., 2004). Other heavy metals are in low concentrations except in samples from the San Quintín area (SQ), where significantly high amounts of $\mathrm{Pb}$ and $\mathrm{Zn}$ were also found (Table 2).

In Idria samples, analysis of total mercury content revealed high concentrations in all samples (Table 2). Those samples taken near the former smelting facilities were the most polluted. This observation can be explained by the settling down of $\mathrm{Hg}$-enriched particles in the immediate vicinity of the smokestack of the smelter. Moreover, the high total $\mathrm{Hg}$ concentration observed in Idria sediments (RS) and in alluvial soils (S4) $40 \mathrm{~km}$ downstream from the mine indicate that sources of mercury such as mercury-bearing rocks, wastes from combustion processes, as well as contaminated river-bed sediments remain the major $\mathrm{Hg}$ input to the aquatic environment in the area even a decade after the end of mining operations.

The total mercury content of soil and dump samples of Asturias mine show the highest mercury content of the three mines studied, with $27350 \mu \mathrm{g} \mathrm{g}^{-1}$ in dump samples (TRRmn116) and $18000 \mu \mathrm{g} \mathrm{g}^{-1}$ in soils from the chimney channel, with high amounts of arsenic content (from $735 \mu \mathrm{g} \mathrm{g}^{-1}$ to $\left.187218 \mu \mathrm{g} \mathrm{g}^{-1}\right)$.

PCA was performed separately for each mining district given the significant differences expected and considering the number of sample XANES spectra (representative enough) available in each case. As stated in $\$ 2.4$, the original set of reference compounds included 11 mercury phases (Fig. 2). In Fig. 2, XANES spectra of samples collected in the three 
Table 2

Average heavy metals content in samples from the three mining districts (in $\mu \mathrm{g} \mathrm{g}^{-1}$ ).

Mercury was analyzed by ZAAS-HFM and As, $\mathrm{Zn}$ and Pb by XRF. BDL: data below detection limits. $\Phi=$ grain size.

\begin{tabular}{|c|c|c|c|c|c|}
\hline Sample & Material & $\mathrm{Hg}$ & As & $\mathrm{Pb}$ & $\mathrm{Zn}$ \\
\hline \multicolumn{6}{|l|}{ Almadén } \\
\hline CH-127 & Dump & 989 & BDL & BDL & 112 \\
\hline HR-108 & Soil & 976 & BDL & 214 & 96 \\
\hline HR-109 & Soil & 404 & BDL & 111 & 104 \\
\hline HR-110 & Soil & 200 & BDL & 130 & 185 \\
\hline RD-124 & $\begin{array}{r}\text { Suspended } \\
\text { particles }\end{array}$ & 105 & BDL & BDL & BDL \\
\hline CH-125 & Sediment & 1800 & BDL & BDL & 112 \\
\hline AZG-105 & Riparian soils & 2816 & 23 & 139 & 233 \\
\hline CH-128 & Riparian soils & 450 & BDL & 102 & 185 \\
\hline ALM-101 & Soil & 2720 & BDL & 74 & 153 \\
\hline ALM-102 & Soil & 2629 & BDL & 102 & 193 \\
\hline CH-126 & Soil & 2230 & BDL & BDL & 365 \\
\hline SQ-111 & Dump & 902 & BDL & 15837 & 6877 \\
\hline SQ-112 & Dump & 1730 & BDL & 2154 & 1221 \\
\hline SQ-113 & Soil & 1935 & BDL & 19049 & 7134 \\
\hline SQ-114 & Soil & 390 & & & \\
\hline \multicolumn{6}{|l|}{ Asturias } \\
\hline TRRmn-115 & Dump & 1470 & 39338 & BDL & BDL \\
\hline TRRmn-116 & Dump & 27350 & 117553 & BDL & BDL \\
\hline TRRs-118 & Chimney soil & 3280 & 735 & BDL & BDL \\
\hline TRRs-121 & Chimney soil & 18000 & 12133 & BDL & BDL \\
\hline TRRmn-122 & Dump & 5785 & 42300 & BDL & BDL \\
\hline TRRfs-3 & Soil & 1570 & 16826 & 107 & 173 \\
\hline TRRfs-4 & Soil & 1080 & 1120 & 53 & 137 \\
\hline TRRc-5 & Calcined & 34 & 187218 & BDL & BDL \\
\hline TRRc-55 & Calcined & 54 & 25876 & BDL & BDL \\
\hline \multicolumn{6}{|l|}{ Idria } \\
\hline S-1 & Soil & 333 & 21 & BDL & 112 \\
\hline S-2 & Meadow Soil & 47 & 26 & BDL & 102 \\
\hline S-4 & Alluvial soil & 76 & BDL & BDL & 64 \\
\hline S-5 & $\begin{array}{l}\text { Soil } \\
\qquad \text { (50 cm depth) }\end{array}$ & 175 & BDL & 47 & 145 \\
\hline S-6 & $\begin{array}{l}\text { Soil } \\
\qquad(100 \mathrm{~cm} \text { depth })\end{array}$ & 144 & BDL & 73 & 496 \\
\hline RS-1 & $\begin{array}{l}\text { Sediment } \\
\qquad \Phi<63 \mu \mathrm{m}\end{array}$ & 6540 & BDL & 302 & 270 \\
\hline RS-2 & $\begin{array}{l}\text { Sediment } \\
\qquad \Phi<2 \mathrm{~mm}\end{array}$ & 1920 & BDL & 14 & BDL \\
\hline SS-1 & $\begin{array}{l}\text { Suspended } \\
\text { particles } \\
\Phi<63 \mu \mathrm{m}\end{array}$ & 96 & BDL & BDL & 449 \\
\hline SS-2 & $\begin{array}{l}\text { Suspended } \\
\text { particles } \\
\Phi<2 \mathrm{~mm}\end{array}$ & 11 & BDL & BDL & 24 \\
\hline S-3 & Soil & 95 & 27 & 46 & 130 \\
\hline $\mathrm{Hg}$ ore & Ore & & & & \\
\hline
\end{tabular}

mining districts are also reported. As examples, Fig. 3 shows the fitted spectra for selected samples from each of the three sites (more data are reported in Table 3).

For the Almadén district, the PCA results indicate that five components [cinnabar ( $\mathrm{Cb})$, metacinnabar (Mc), $\mathrm{HgCl}_{2}$, $\mathrm{Hg}_{2} \mathrm{Cl}_{2}$ and schuetteite $\left.(\mathrm{Sc})\right]$ can be used to reconstruct each of the experimental spectra (depending on the sample) above the $95 \%$ confidence level. Mercury sulfides are the most common species found in almost all samples (Table 3), especially in those collected in abandoned metallurgical plants like Almadenejos area and Huerta del Rey (Almadén area). Non-sulfide phases like schuetteite $\left[\mathrm{Hg}_{3}\left(\mathrm{SO}_{4}\right) \mathrm{O}_{2}\right]$, calomel $\left(\mathrm{Hg}_{2} \mathrm{Cl}_{2}\right)$ and

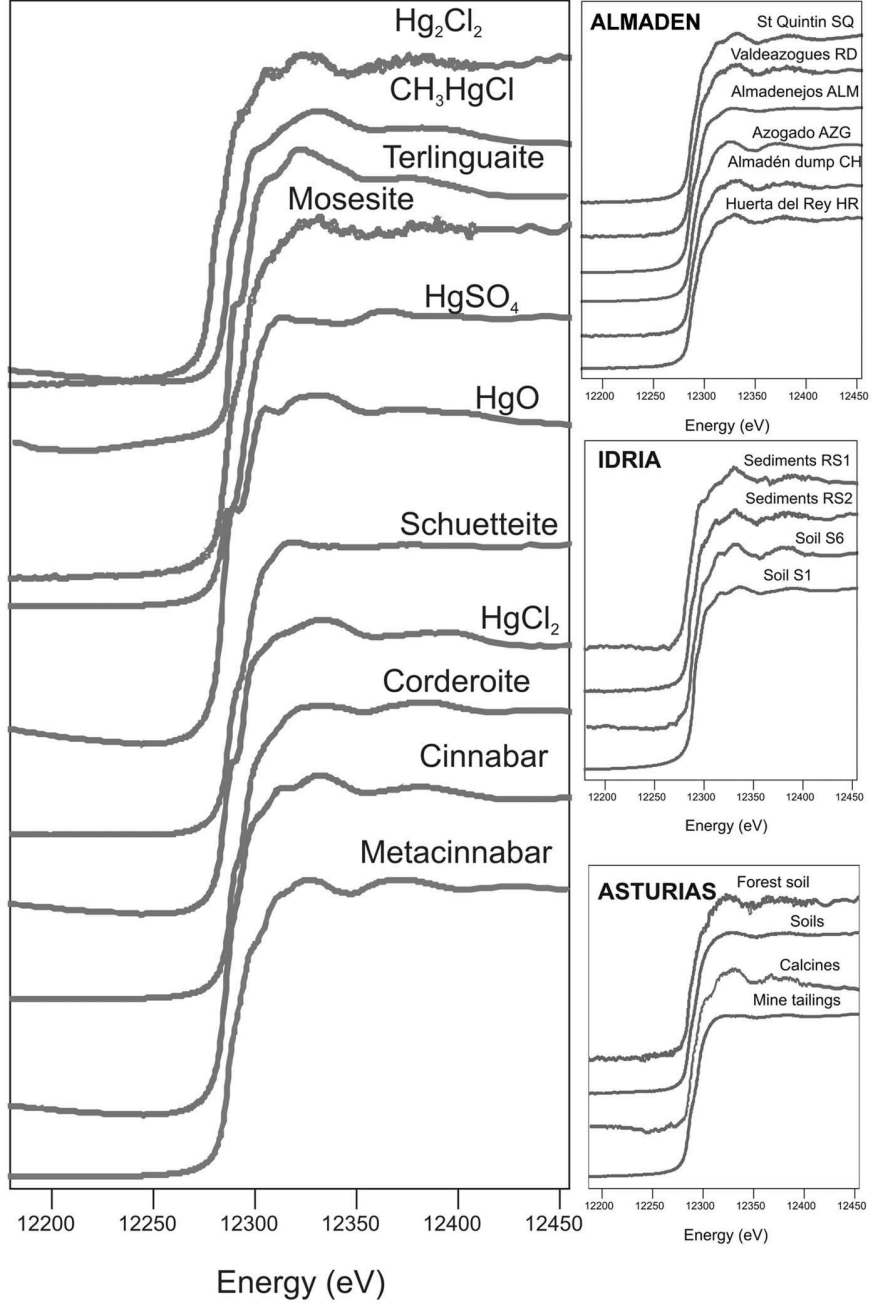

Figure 2

XANES spectra of selected $\mathrm{Hg}$ pure compounds and samples from Almadén, Idria and Asturias mining districts (all spectra are deliberately displaced to show differences). Each spectrum corresponds to the mean value of five replicates.

mercuric chloride $\left(\mathrm{HgCl}_{2}\right)$ are present in different ratios in soil and sediment samples.

XANES analyses in the samples from San Quintín area (see Table 3) have shown the absence of metacinnabar but high amounts of cinnabar $(47-59 \%)$ and minor amounts of relatively more soluble species like calomel (24-33\%) and schuetteite (17-21\%) which can be attributed to weathering processes. The absence of metacinnabar, a metastable polymorph of cinnabar which occurs during the roasting process of mercury ores in the presence of impurities (Dickson \& Tunell, 1959), is due to the historical use of the site, as only flotation tests were performed and no furnaces were used there.

On the other hand, metacinnabar has been identified in soil samples from Almadenejos (ALM) (31-39\%) and Huerta del Rey (HR) $(\sim 23 \%)$, locations with known historic metallurgical activity.

Other non-sulfide phases like mercurous chloride (24-43\%) have also been identified at San Quintín and Huerta del Rey, and can be attributed to the process of soil formation. High 
Table 3

Main mercury species (in \%) and mobile mercury (in $\mathrm{mg} \mathrm{L}^{-1}$ and \%).

Abbreviations: $\mathrm{Cb}$, cinnabar; Mc, metacinnabar; Sc, schuetteite; Co, corderoite; BDL, below detection limits.

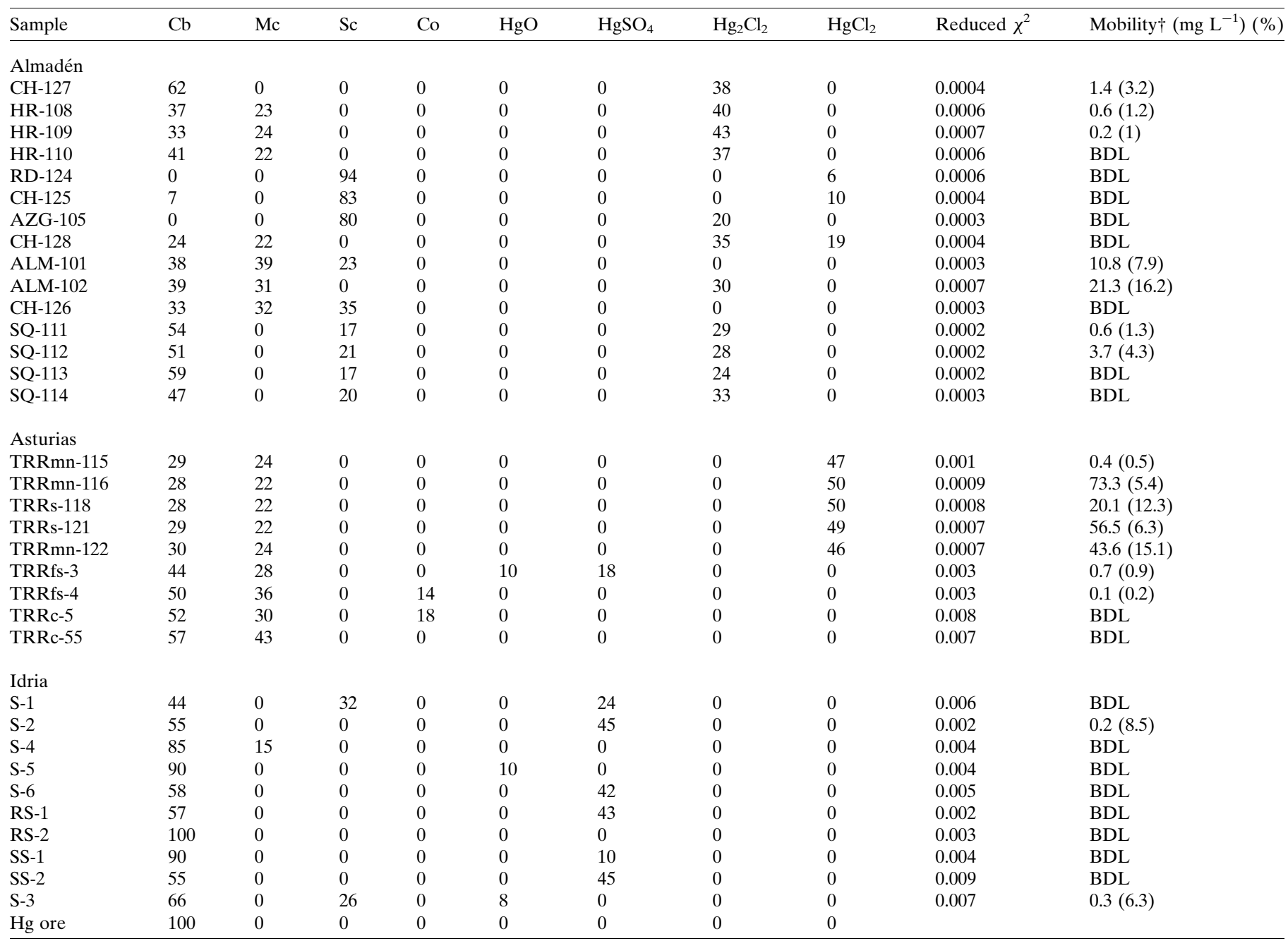

$\dagger$ Determined according to the method of Perez et al. (2008).

amounts of schuetteite have been identified in ore stockpile in San Quintín and Almadenejos area. This is a mineral phase typically linked to the presence of $\mathrm{Hg}^{0}$ that appears in the sunlight-exposed side of the rock surface, and it is frequently found near old furnaces or ore dumps (Higueras et al., 2003).

High proportions of relatively more soluble phases have been identified in soil and sediment samples from Valdeazogues River (100\%) and Azogado stream (100\%). These phases $\left[\mathrm{Hg}_{2} \mathrm{Cl}_{2}, \mathrm{HgCl}_{2}\right.$ and $\left.\mathrm{Hg}_{3}\left(\mathrm{SO}_{4}\right) \mathrm{O}_{2}\right]$ have been considered a result of the weathering processes taking place within the drainage network of the mining district. The mobility of mercury in this district is clearly linked with metallurgical activity and formation of secondary chloride phases. The highest mobility was found in soil samples from an old metallurgical precinct (ALM) (10.8-21.3 $\mathrm{mg} \mathrm{L}^{-1}$; see Table 3).

At the Idria mining district the PCA analysis reveals the presence of five components $\left(\mathrm{Cb}, \mathrm{Mc}, \mathrm{Sc}, \mathrm{HgO}, \mathrm{HgSO}_{4}\right)$. In this district, cinnabar is the most common $\mathrm{Hg}$ form in soil, sediments and suspended particles, while the presence of metacinnabar is found in a soil sample (S-4), and sulfates in soils and sediments (S, RS, SS). The lack of metacinnabar in most of these samples is due to the re-use of calcines and metallurgical wastes in the refilling of mine galleries with minor dispersion of this material throughout the surrounding environment. High proportions of sulfates were found in soil samples (S), but the mobility of mercury in this district was clearly reduced, mainly by the major proportions of cinnabar in soils, sediments and suspended particles. This low mobility of mercury (0.2-0.3 mg L ${ }^{-1}$, see Table 3 ) is in accordance with Kocman (2008), describing low water-soluble mercury species in sediments and suspended particles.

In Asturias mining district, the PCA analysis needs six components to reconstruct samples spectra $[\mathrm{Cb}, \mathrm{Mc}$, corderoite (Co), $\mathrm{HgCl}_{2}, \mathrm{HgO}, \mathrm{HgSO}_{4}$. All samples from the decommissioned mine and metallurgical facility show high mercury contents in soils (TRRfs), dump materials (TRRmn) 


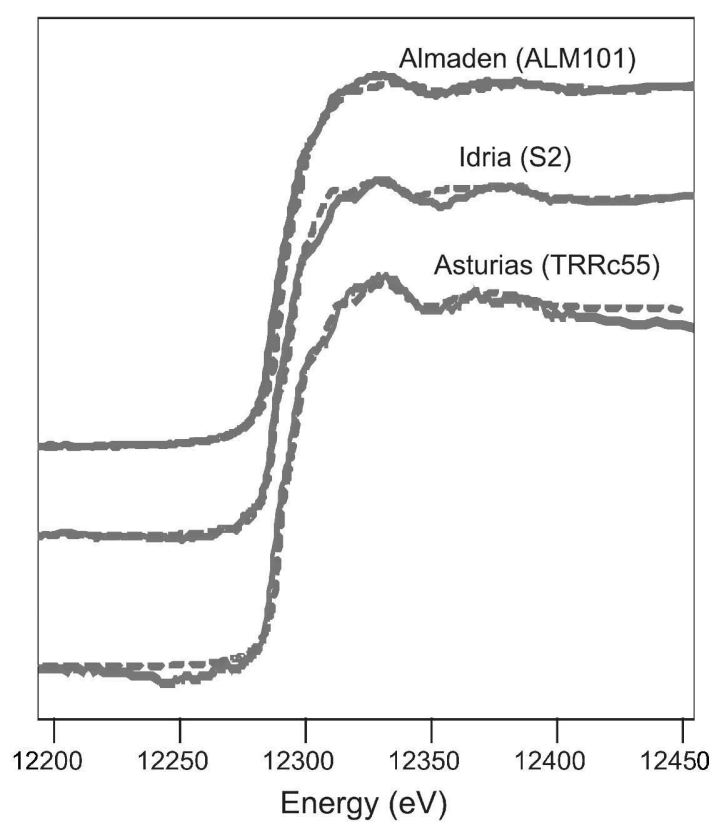

Figure 3

XANES spectra of selected samples from the three mining districts with reconstructed spectra shown as dashed lines. (See Table 3 for more details.)

and chimney soils (TRRs) (Table 2), and a predominance of sulfides species $(50-100 \%)$ with significant presence of metacinnabar in all samples (Table 3). Ratios between cinnabar and metacinnabar in these samples are lower than in Almadén area, where metallurgical activity was not the predominant activity. In this mining site, metallurgy was less efficient than in Idria and Almadén area, with lower roasting temperature and poorest recovery rates. The contents of other mercury species such as chlorides are significant, with high amounts on soils samples from the facility and the chimney exhausting roasting smokes. The mobility of mercury in this district is higher than in Almadén. In qualitative terms, the percentage of mobile mercury agrees well with the presence of $\mathrm{HgCl}_{2}$ except for TRRmn-115. In general, it is important to point out that it is likely that the methodology applied to assess $\mathrm{Hg}$ mobility only extracts a fraction of the $\mathrm{HgCl}_{2}$ present, thus underestimating Hg mobility.

If we consider the three districts, the main processes affecting mercury speciation are ore composition, mining history and roasting process. The type of metallurgical processing arises as one of the most important factors in defining mercury availability: mercury mobility is higher in Asturias district owing to the inefficient roasting treatment used (lower roasting temperatures and poorer recovering rates); the mobility is significantly lower in the Almadén district, with better furnaces (only in the last century) and despite the complex and lengthy history of mining and metallurgical activity. On the other hand, the even lower mobility values found in Idria district are related to its efficient metallurgical process (similar to Almadén area), together with the appropriate management of calcines used for refilling old galleries and the shorter mining history of the district.

\section{Conclusions}

This work represents the first inter-regional study of mercury speciation of the two main European $\mathrm{Hg}$-mining districts (Almadén and Idria), and a polymetallic district located in Asturias.

XANES has provided key information on the inorganic mercury speciation of ores, calcines, dump material, soils, sediments and suspended particles samples. Rather insoluble mercury compounds (cinnabar, metacinnabar, schuetteite, corderoite) have been shown to prevail in dumps and wastes from mines and metallurgical plants, whereas more soluble $\mathrm{Hg}$ phases (mainly $\mathrm{HgCl}_{2}$ but also $\mathrm{HgO}$ and $\mathrm{HgSO}_{4}$ ) were found in soils and sediments from all target areas. A qualitative relationship between mobile mercury and the presence of mercury chlorides or sulfates compounds has been established for samples from the three districts. Nonetheless, the absolute 'mobility' remains relatively low in most cases, inherently suggesting that kinetic effects and availability of the soluble phases might also be considered in the assessment of mercury behaviour.

Synchrotron experiments at HASYLAB were financially supported by the European Community, Research Infrastructure Action under the FP6 'Structuring the European Research Area' Programme (through the Integrated Infrastructure Initiative 'Integrating Activity on Synchrotron and Free Electron Laser Science'). Financial contribution from the projects PPQ2003-01902, CTQ2005-09430-C05 and CTM200613091-C02-02/TECNO funded by the Spanish Ministry of Science and Innovation is also acknowledged.

\section{References}

Arai, J., Lanzirotti, A., Sutton, S. R., Newville, M., Dyer, J. \& Sparks, D. L. (2006). Environ. Sci. Technol. 40, 673-679.

Bernaus, A., Gaona, X., Esbrí, J. M., Higueras, P., Falkenberg, G. \& Valiente, M. (2006a). Environ. Sci. Technol. 40, 4090-4095.

Bernaus, A., Gaona, X., Ivask, A., Kahru, A. \& Valiente, M. (2005b). Anal. Bioanal. Chem. 382, 1541-1548.

Bernaus, A., Gaona, X. \& Valiente, M. (2005a). J. Environ. Monit. 7, 771-777.

Bernaus, A., Gaona, X., van Ree, D. \& Valiente, M. (2006b). Anal. Chim. Acta, 565, 73-80.

Berzas Nevado, J. J., García Bermejo, L. F. \& Rodríguez MartínDoimeadiós, R. C. (2003). Environ. Pollut. 122, 261-271.

Biester, H., Gosar, M. \& Covelli, S. (2000). Environ. Sci. Technol. 34, 3330-3336.

Biester, H., Gosar, M. \& Müller, G. (1999). J. Geochem. Explor. 65, 195-204.

Bloom, N. S., Preus, E., Katon, J. \& Hiltner, M. (2003). Anal. Chim. Acta, 479, 233-248.

Catalano, J. G., Trainor, T. P., Eng, P. J., Waychunas, G. A. \& Brown, G. E. (2005). Geochim. Cosmochim. Acta, 69, 3555-3572.

Dickson, F. W. \& Tunell, G. (1959). Am. Mineral. 44, 471-487.

Förstner, U. (1998). Integrated Pollution Control, edited by A. Weissbach and H. Boeddicker, pp. 81-130. Berlin: Springer-Verlag. García-Sansegundo, J., Lorenzo, S. \& Ortega, E. (1987). Servicio de Publicaciones, Ministerio de Industria y Energía, Madrid, p. 60.

Gray, J. E., Hines, M. E., Higueras, P., Adatto, I. \& Lasorsa, B. K. (2004). Environ. Sci. Technol. 38, 4285-4292.

Hall, C. M., Higueras, P. L., Kesler, S. E., Lunar, R., Dong, H. \& Halliday, A. N. (1997). Earth Planet. Sci. Lett. 148, 287-298. 


\section{soil and geosciences}

Harris, H. H., Pickering, I. J. \& George, G. N. (2003). Science, 301, 1203.

Hernández, A., Jébrak, M., Higueras, P., Oyarzun, R., Morata, D. \& Munhá, J. (1999). Miner. Deposita, 34, 539-548.

Higueras, P., Oyarzun, R., Biester, H., Lillo, J. \& Lorenzo, S. (2003). J. Geochem. Explor. 80, 95-104.

Higueras, P., Oyarzun, R., Lillo, J., Sánchez-Hernández, J. C., Molina, J. A., Esbrí, J. M. \& Lorenzo, S. (2006). Sci. Tot. Environ. 356, 112 124.

Higueras, P., Oyarzun, R., Munhá, J. \& Morata, D. (2000). Rev. Soc. Geol. Esp. 13, 10-119.

Horvat, M. (2005). Dynamics of Mercury Pollution on Regional and Global Scales: Atmospheric Processes and Human Exposures Around the World, edited by V. Pirrone, N. Mahaffey and R. Kathryn, pp. 154-190. New York: Springer.

Horvat, M., Jereb, V., Fajon, V., Logar, M., Kotnik, J., Faganeli, J., Hines, M. \& Bonzongo, J. C. (2002). Geochem. Explor. Environ. Anal. 2, 287-296.

Kanduč, T., Kocman, D. \& Ogrinc, N. (2008). Aquat. Geochem. 14, 239-262.

Kim, C. S., Bloom, N. S., Rytuba, J. J. \& Brown, G. E. (2003). Environ. Sci. Technol. 37, 5102-5108.

Kim, C. S., Brown Jr, G. E. \& Rytuba, J. J. (2000). Sci. Tot. Environ. 261, 157-168.

Kim, C. S., Rytuba, J. J. \& Brown Jr, G. E. (2004). Appl. Geochem. 19, 379-393.

Kocman, D. (2008). PhD thesis, Vol XIII, pp. 152, Jozef Stefan International Postgraduate School, Slovenia.

Kocman, D., Horvat, M. \& Kotnik, J. (2004). J. Environ. Monitor. 6, 696-703.
Loredo, J., Ordoñez, A., Gallego, J. R., Baldo, C. \& García-Iglesias, J. (1999). J. Geochem. Explor. 67, 377-390.

Luque, C. \& Gutiérrez, M. (2006). Editors. La Minería del Mercurio en Asturias: Rasgos Históricos, 1st ed.

Malinowski, E. R. (1991). Factor Analysis in Chemistry, 2nd ed. New York: Wiley.

Perez, G., Lopez-Mesas, M. \& Valiente, M. (2008). Environ. Sci. Technol. 42, 2309-2315.

Rehr, J. J., Albers, R. C. \& Zabinsky, S. I. (1992). Phys. Rev. Lett. 69 , $3397-3400$

Ressler, T., Wong, J., Roos, J. \& Smith, I. L. (2000). Environ. Sci. Technol. 34, 950-958.

Riddle, S. G., Tran, H. H., Dewitt, J. G. \& Andrews, J. C. (2002). Environ. Sci. Technol. 36, 1965-1970.

Saupé, F. (1990). Econ. Geol. 85, 482-510.

Sholupov, S. E. \& Ganeyev, A. A. (1995). Spectrochim. Acta B, 50, 1227-1238.

SIXPack (2004). SIXPack - Sam's Interface for XAS Analysis Package, powered by IFEFFIT 1.2.6. Copyright Matt Newville, University of Chicago, USA.

Slowey, A. J., Johnson, S. B., Rytuba, J. J. \& Brown, G. E. (2005a). Environ. Sci. Technol. 39, 7869-7874.

Slowey, A. J., Rytuba, J. J. \& Brown, G. E. (2005b). Environ. Sci. Technol. 39, 1547-1554.

Sumozas, R. (2005). PhD thesis, Castilla-La Mancha University, Spain.

Wasserman, S. R., Allen, P. G., Shuh, D. K., Bucher, J. J. \& Edelstein, N. M. (1999). J. Synchrotron Rad. 6, 284-286.

Webb, S. M. (2005). Phys. Scr. T115, 1011-1014. 